\title{
The Various Factors Affecting The Competence Of The Human Resources In increasing Competitiveness In The Hospitality Industry
}

\author{
Femmy Indriany Dalimunthe ${ }^{1}$ \\ Medan Tourism Polytechnic \\ Medan, Indonesia \\ femmydalimunthe@yahoo.co.id
}

\author{
Muhammad Halfi Indra Syahputra ${ }^{2}$ \\ Medan Tourism Polytechnic \\ Medan, Indonesia \\ halfimedan@gmail.com
}

\author{
Sumihar Sebastiana Sitompul ${ }^{3}$ \\ Medan Tourism Polytechnic \\ Medan, Indonesia \\ sumiharsebastiana2@gmail.com
}

\begin{abstract}
The Tourism and Hospitality Sector is supported by the human resources who are qualified and competent in their fields. Hotels need professional and loyal workers to provide the best service and be able to survive in the era of competition. The purpose of this study is to investigate the competency (educationbackground and skills) of the human resources as the one of the most important factors in the hospitality industry and the role of the triple helix system (industry, government and academics) because in servicebased organizations, human resources play a role as the key factor in determining company performance.

This research is a survey method and used quantitative analysis. The population are the workers of the Front Office Department, Housekeeping Department and F\&B Service Department of the Grand Inna Parapat Hotel and Siantar Hotel Parapat. The sample are taken by using purposive sampling.

The results showed that the educationlevel of human resources in various departments was mostly at the level of secondary school education. The level of skills possessed by the human resources in various departments is more certified. The role of the 'triple helix' system (industry, government and academia) requires better integration. The competencies of hotel and restaurant employees are prepared since they are in advanced education. Then, the industries should continue to link and interact with the government and academics.
\end{abstract}

Keywords: level of education, level of skills, triple helix

\section{INTRODUCTION}

The tourism sector can not be separated from the development of the hotel and the restaurant industry. It is supported by the qualified and competence of human resources in their field. In the era of the Asean Economic Community (AEC), the human resources that will be employed by the industry is the human resources who have the competence and have the capability to meet the service standards and certification nationally or internationally. Developing the competence is important along with their convenience for foreign workers to work in Indonesia. This is a threat to Indonesian workers if not prepared with the competencies required by the industry and to ensure that Indonesian workers will not be the spectators in their own country.

Many factors affect the competence of the human resources. Education factor is one of them. With the provision of education, human resources will be ready to face this competition era. However, until now, there is still a mismatch and the linkages between education and the hotel industry. The discrepancy between the educational background and their competence will produce the competencies that are not suitable with the industry expectation

Skills are also affecting the competitiveness of the human resources in hotel industry. This can be evidenced through the certification process. The importance of certification for human resources in the hospitality industry is the legal proof that human resources are truly expert and skilled in their field. Educational background and skills of the hotel workers were tested to obtain the certificate. Certification competencies provide benefits for the company and the certification holder. But so far there are still many hotel employees who do not have a certificate of competence in their field. In this regard, the role of government, academics and industry are essential to be able to support the certification process that has been launched by the government. Especially for the company, the human resources that have been certified means has met the Labor Law no.13 of 2003 and Government Regulation No. 23 of 2004 and Government Regulation No.31 of 2006 on the national job training system.

In addition to the above two factors, the role of government, academia and industry is important to prepare the competence of the workers to be able to compete in this era of globalization. The government plays a role in establishing policies and programs to increase the competence of human resources in the hospitality industry. Academics in this case serves as a provider of higher education and training of professional human resources, while the industry was the instrument in preparing a business environment where human resources in the hospitality field for practice (on the job training and 
off-the-job training). System triple helix that is cooperation between government, academia and industry above will influence the improvement of the competence of human resources in the hospitality industry. Based on the above background, it is necessary to research on "Various Factors Affecting the Human Resource Competency in Increasing Competitiveness in the Hospitality Industry. "

\section{Research problems}

From the above background, the problem consists of:

1. How is the educational background of the human resources in the department of the Front office, Housekeeping and F\&B Services?

2. How is the skills of the human resources in the department of the Front office, Housekeeping and F\&B Services?

3. How is the role of the 'triple helix' system (industry, government and academia) in improving the competence of human resources?

\section{Research purposes}

The purpose of this study is:

1. To determine the educational background of the human resources in the department of Front office, Housekeeping and F\&B Services.

2. To determine the skills on the human resources department of the front office, housekeeping and meal planning.

3. To determine the role of the 'triple helix' system(industry, government and academia) in improving the competence of human resources.

\section{Theoretical Review}

Human resources in the tourism industry is one important factor for service companies (service-based organization) because $\mathrm{HR}$ role as a key factor in determining the performance of the company.Hull (2005: 8) states that academic achievement is also one thing that is very much appreciated by the industry. This means that academic performance will affect a person's career in the working industry. Most graduates are prepared to work in the industry started early in his career with a formal educational background (Guide to College Programs, 2004).

Entry level when starting the career in the industry will be influenced by education and work experience. In accordance with the above statement, there is substantial evidence that the educational attainment of a person associated with a positive career outcomes, including the level of salary, promotion, development opportunities and job mobility both in the fields of economy, labor and organizational science(Cappelli, 2000; Howard, 1986; Lazear, 1981; Ng, Eby, Sorensen, and Feldmen, 2005). This is due to most companies use education as one of the indicators to assess a person's skills or productivity (Benson, Finegold \& Mohrman, 2004). They always use education as a prerequisite in the decision to hire someone.

Previous research has found that the industry has not yet fully appreciate the bachelor/diploma of hospitality that began his career in the hospitality industry. They always compete with students of secondary school graduates who have qualified more on work experience (Connor \& Pollard, 1996; Harkison, 2004b; Jameson \& Holden, 2000; Li \& Kivela, 1989; Mason, 1995; Petrova $\&$ Mason, 2004). Dalimunthe (2017) in her study stated that the diploma 3 graduates even has the same entry level with the secondary vocational school graduates. Thus, the hospitality industry prefer the employees with experience to the diploma graduates. It is very noticeable contrast with the expectations of most people who think that a college degree would give a person the advantages regarding work in his chosen field (Jameson \& Holden, 2000).

Academic skillsis one factor that supports a person's career. Tesone and Ricci (2012: 1) states that the relationship between education factor to the success of potential industry is still an important area for the study of hospitalityliterature. Ladkin (2000: 231) emphasizes that the level of higher education is to make sure someone when enteringthe industry will be the assistant manager level, while those with lower levels of education starting from supervisor level or department head. This is in line with Geel and Gellner (2011: 2) state that for the graduates, the success of the entry level after attending a college education is very important because it is a long investment period and cost. With the provision of education in the college, the graduates will gain access as a step to a higher career, interesting job and desirable.

Ladkin (2002) believes that the education is an essential starting point in the career development and as the basis of the careeranalysis. In addition, there is a correlation between the level of educational success and career development of individuals. Individuals with higher levels of education are making progress in the organizational structure. In line with the above statement,Geel and Gellner (2011) examined how the type of high-vocational education or public school education influence early career and success in the job market after graduation. The results show that vocational graduates face a smaller risk for the beginning of his career than the public school graduates.

Prosser (1950) suggested theories in vocational education, known by Prosser sixteen theorems on vocational education: A basis for vocation phylosophy. Six of the sixteenth theory is as follows. First, vocational education will be efficient when provided a learning environment that suits the environment in which they will work. Second, an effective vocational training can only be granted if the assigned task in practice have the same equipment and machines similar to those used in the workplace. Third, vocational education will be effective if since exercise is already accustomed to the behavior which should be addressed in future work experience. 
Fourth, vocational education instructors must be experienced and apply the skills in teaching. Fifth, education should be familiar with working conditions and match the industry need. Sixth, the most appropriate data sources to determine the educational material is closely connected with the work.

According Kepmendiknas No. 045 / U / 2002, the competence is a set of intelligent action, the full responsibility of a person as a condition to be considered capable by the public in carrying out tasks in certain occupations. In accordance with the Decree of the Minister of Manpower and Transmigration No. 229 of 2003, the job competencies is the ability of each individual that covers aspects of knowledge, skills, and attitudes that work in accordance with established standards. PDRI and Aguirre International (2005: 4) states that "a competency is the capability to apply or use a set of related knowledge, skills, and abilities required to successfully perform" critical work functions "or tasks in a defined work setting." More further Ennis (2008: 4) states that "a competency is the capability of applying or using knowledge, skills, abilities, behaviors, and personal characteristics to successfully perform critical work tasks, specific functions, or, operate in a given role or position." The fourth is based on the above definition can be seen that competence covers aspects of knowledge (knowledge), skills (skills) and attitude (attitude) about work in a particular field.

Some experts define the term of competence as follows: Competence encompasses an individual's technical and interpersonal knowledge and skills (Robbins, Stephen P 2010: 357). Competence is the individual knowledge and skill of technical and interpersonal. characteristics on that is causally related to criterion referenced effective and / or superior performance in a job or situation (Spencer and Spencer 1993: 9). Competence relates to the basic characteristics of individuals associated with the effective performance standards and or superior. Competence Refers to an individual's knowledge, skills, abilities or personality characteristics that directly influences his or her performances (Becker, Huselid, and Ulrich in Yuniarsih and Suwatno 2008: 22). Competence is the knowledge, skills, abilities, and personality that directly affect

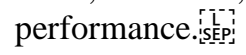

Competence according to the Law No. 13 of 2003 on employment are: the ability of each individual that covers aspects of knowledge, skills, and attitudes that work in accordance with established standards. Work competency standards for Indonesia stipulated in SKKNI (National Competence Indonesia) issued by the Ministry of Manpower and Transmigration. Indonesian National Competence (SKKNI) is a description of capabilities that include knowledge, skills and attitudes that must be possessed minimal work to occupy certain positions. Work competency standards a formula that really worked in the workplace in the industry.
Hinckley and Hull \& (2008: 42) states that the knowledge and skills included in the career and technical skills are part of the curriculum that will be required for graduate students at the same time in starting his career as well as the next steps to pursue his career path. From the above statement can be explained that the knowledge and skills is a component of career and technical skills that support the career path.

The tourism industry has the potency to be developed. This is consistent with what has been proclaimed by the President, Mr. Ir. Joko Widodo that Tourism is the $2^{\text {nd }}$ Leading Sector after agriculture. Thus we need to support the cooperation between academia/scholars (intellectuals), industry/business and the government, the so-called Triple Helix. Triple Helix systemis an activator of creativity, ideas, and skills (Etzkowitz, 2008). Parties are considered to be able to provide assistance for the development of the hospitality industry namely intellectuals, government and business (Triple Helix). Collaboration of the three actors of Triple Helixisto enhance creativity, ideas and skills (Etzkowitz, 2008).

Academics or intellectuals is a provider of human resources and knowledge, as well as socio-economic development actors. Academia liable to produce professional workers in the field of hospitality. Triple helix illustrates the importance of cooperation between universities or educational institutions, government and industry. Triple helix system aims to improve the cycle of cooperation between universities, industry and government as an agent of development,because if it hampered the cooperation cycle could lead to delays in the development of human resources professionals in the field of hospitality.

Educational institutions have the following roles: Develop a curriculum based on the competencies needed at present and make predictions about the competencies needed.

b) Perform quality learning process.

c) Conducting research / study results can be applied to the hotel and restaurant industry.

d) Perform professional certification.

The industry in the triple helix system is the hospitality industry. The industry has a standard criteria expected for human resource. Mix and match factors between the industry and academia determine the expected graduate profile in hospitality industry. Standard criteria needed can be input to determine the competencies expected. In this case the hotel industry is obliged to provide training (on the job and off the job training) in accordance with the level of education to human hospitality. This will ensure that the human resources competence expected by the industry can be adjusted to the level of education. The hospitality industry as the training institutions have the following roles: is i

a) Implement competency enhancement training.

b) Perform professional certification. 
Government, including The Ministry of Tourism of the Republic of Indonesia and the Labor Department of Simalungun Regency has a role to establish a national competency standards (SKKNI) and establish policies and programs to human resources in hotels and restaurants sector gradually competence according SKKNI.

\section{RESEARCH METHODS}

This type of research is quantitative research that aims to explain something and describe the results of the analysis has been calculated and used survey method.The location of this study is at Siantar Parapat Hotel and Grand Inna Hotel Parapat in Simalungun Regency and using purposive-sampling technique. The samples taken were hotel employees who work in the department of Front Office, Housekeeping, F\&B Services in Grand Inna Hotel Parapat and Siantar Hotel Parapat, Simalungun Regency.

Data collection techniques used in this research is observation, questionnaires and interviews to the employees Siantar Hotel Parapat and Grand Inna Hotel Parapat in Simalungun Regency. Data is analyzedusing the techniques of analysis of variance for the independent variables are categories:

$$
\begin{aligned}
& \mathrm{X} 1=\text { Level of Education Human Resources } \\
& \mathrm{X} 2=\text { Human Resources Skills } \\
& \mathrm{Y}=\text { Competence }
\end{aligned}
$$

\section{RESEARCH RESULT}

The characteristics of respondents surveyed by gender, there are $74.6 \%$ male and $25.4 \%$ female. Departments involved in this research is the front office $22.2 \%$, food and beverage $39.7 \%$ and housekeeping $38.1 \%$. Most $(88.9 \%)$ educational background of the employees are SMA / SMK, while others had a Diploma $(6.3 \%)$ and undergraduate S1 (4.8\%). Competency certificate owned by $58.7 \%$ of employees, while the remaining $41.3 \%$ has not been certified.

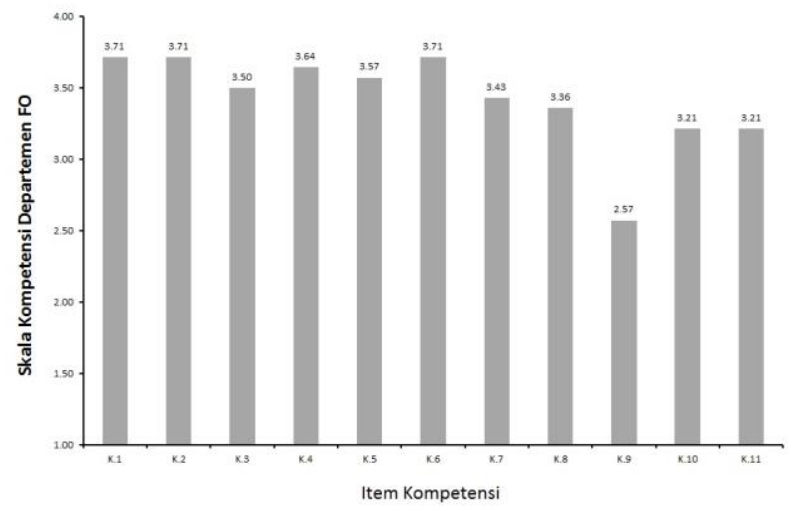

Figure 1. Competence of FO Department

There are 11 assessment items of the competence in the FO Department are as follows:
1. Pre-registration activities (preparing documents for reception)

2. Receive and distribute a phone call.

3. Receive room reservation.

4. Carry out registration of guests who will be staying.

5. Handles the guest departure.

6. Documenting registration (creating registration records)

7. Determination of the number of rooms and room rates (assigning the room and rate)

8. Handle guests belongings.

9. Setting up a room and create sales reports.

10. Handle guest complaints.

11. Doing archiving, including the joys and sorrows of the guests during their stay at the hotel, which will be used as an evaluation, feedback, guest history / record.

Assessment scale 1-4, all items of FO competence with an average of more than 2.5 is included in the good category. Some item competence of FO with a value of less than 3.5 is considered the items that need to be improved, namely: the determination ofthe guests room and the room rates, assigning the room and rates, handling of guests luggage and make room sales reports, handles guest complaints, the archiving process, including the joys and sorrows of the guest during the stay at the hotel, which will be used as an evaluation, feedback, guest history / record.

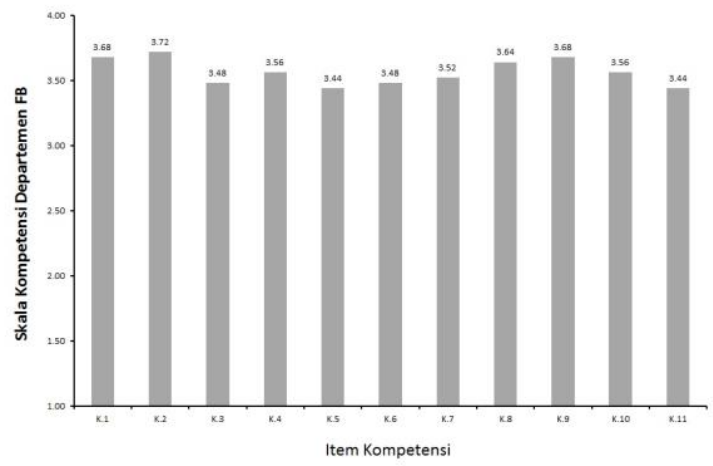

Figure 2. Competence of FB Department

There are 11 assessment items of competence in FB departmare as follows:

1. Greetings and deliver guests to the dinner table.

2. Opening the sitting chair and seated the guests.

3. Providing a list of menu

4. Taking the guest orders

5. Do service in the restaurant.

6. Prepare and set up the table.

7. Clear up the table.

8. Prepare and serve the food buffet.

9. Conduct food and beverage service to the guest rooms/ room service.

10. Handle the guest bill payment.

11. Close the restaurant area / dining area.

Assessment scale 1-4, all items of FB competence with an average of more than 2.5 is included in the good 
category. Some competence item of FB with a value of less than 3.5 is considered the items need to be improved, namely: providing a list of the menu, doing service at the restaurant, preparing and setting the table and close the restaurant area / dining area.

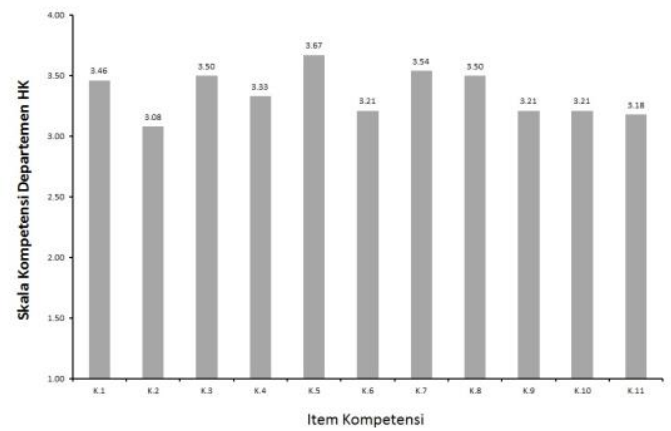

Figure 3. Competence of HK Department

Competence at HK department there are 11 assessment items are as follows:

1. Effective selection against a stock of goods cleaners and how to use properly.

2. Make up rooms under its responsibility.

3. Maintaining the hotels belonging in the guest rooms.

4. Replenish the guest amenities in the guest room such as soap, shampoo, tooth paste, stationary, and others.

5. Doing stripping or taking out the trash, pull out guest bed linen and towels were dirty.

6. Cleaning the bathroom.

7. Cleaning the carpet / floor.

8. Making bed.

9. Dusting.

10. Turning off lights, air conditioning and close the curtain after guests left the hotel.

11. Carry out orders from superiors, both associated with the execution of daily tasks as well as extra jobsto maintain the rooms, as well as the tasks associated with the preparation and the arrival of the hotel guests.

Assessment scale 1-4, the entire item of $\mathrm{HK}$ competence with an average of more than 2.5 is included in the good category. Some competence of HK with a value of less than 3.5 is considered the items that need to be improved, namely: Effective selection against a stock of goods cleaners and how to use properly, make up roomunder its responsibility, replenish the guest amenities in the guest room such as soap, shampoo, tooth paste, stationary, and others, cleaning the bathroom, dusting, turn off the lights, air conditioning and close the curtain after guests left the hotel, carrying out orders from superiors, either related to the execution of daily tasks and extra job, to the maintain the rooms, as well as the tasks associated with the preparation and the arrival of the hotel guests.

\section{Education and Competence}

Competence in each department rated on 11 items with a scale of $1-4$, so the score competencies will range from 11 - 44. Employees with final education at diploma or undergraduate level S1 has a better level of competence.

Table 1. Competence Based Education Level

\begin{tabular}{lccc}
\hline Last education & Average & $\mathrm{N}$ & $\begin{array}{c}\text { Std. } \\
\text { Deviation }\end{array}$ \\
\hline SMA / SMK & 37.61 & 56 & 5.10 \\
D1 / D2 / D3 & 40.25 & 4 & 3.86 \\
S1 & 41.33 & 3 & 3.78 \\
\hline Total & 37.95 & 63 & 5.03 \\
\hline $\mathrm{F}=1.238 ; \mathrm{p}=0.297$ & & &
\end{tabular}

The results of the ANOVA statistical test, obtained $F=1.238$ ( $p>0.05)$ explains that there is no significant difference in the competence of the various levels of education. Although descriptively average competence of the employees with SMA/SMK educational background is the lowest, but statistically, there is no so much different with the employees of diploma or $\mathrm{S} 1$ educational background.

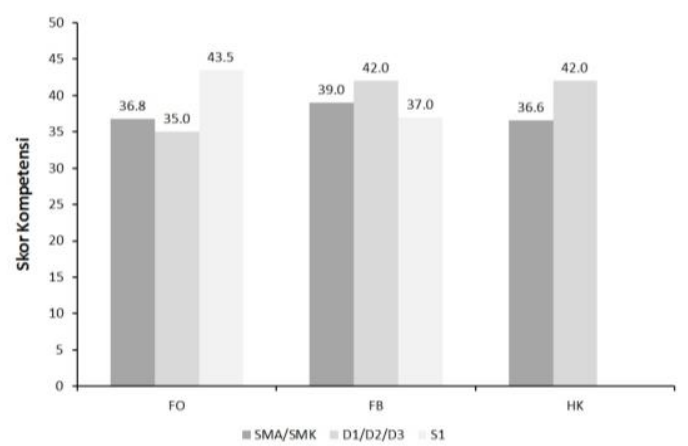

Figure 4. Relationship With Level Competence Various Department of Education

In the various departments, the higher levels of education tend to have better competence, especially in the department of FO and HK. In this research, in the HK department, there is no respondents with undergraduate education level (S1).

\section{Skills and Competencies}

The skills of its employees are described with a certificate. Descriptively, employees were certified competent better compared with that yet. 
Table 2. Competence Based on Level of Expertise

\begin{tabular}{lccc}
\hline certifications & Average & $\mathrm{N}$ & $\begin{array}{c}\text { Std. } \\
\text { Deviation }\end{array}$ \\
\hline already & 38.92 & 37 & 3.74 \\
Not yet & 36.58 & 26 & 6.26 \\
\hline Total & 37.95 & 63 & 5.03 \\
\hline $\mathrm{F}=3.445 ; \mathrm{p}=0.068$ & & &
\end{tabular}

The results of the ANOVA statistical test, obtained $\mathrm{F}=3.445(\mathrm{p}<0.10)$ explains that there is a significant difference between the competence of employees who are certified with uncertified. Competence certified employees is higher than those who do not have certificates.

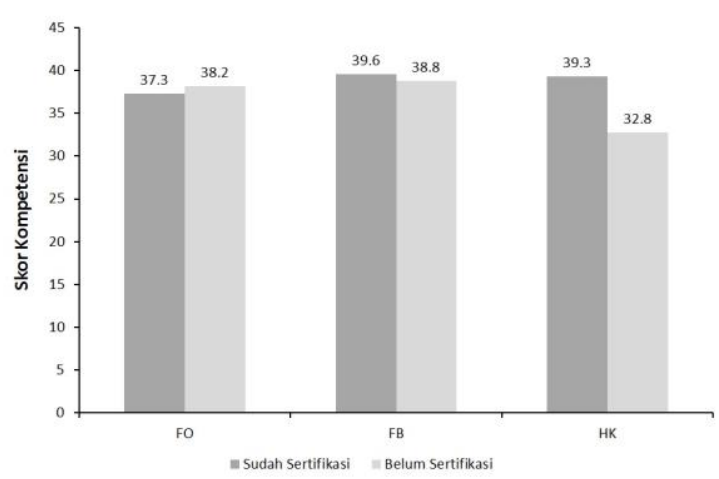

Figure 5. Relations Department With Various Competency Certification

In the various departments, employee skills shown by the owning the certificate of competence. Employees that have a certificate of competence tend to have better competence, especially in the department of FB and HK. While the FO department is not much different competencies among employees that have not been certified.

\section{Discussion \\ Human Resource Education}

One's educationis a process of improvement and development capabilities of individual work accomplished in order to achieve the desired career. Education in career development includes courses, formal education, and training. Between the three components of this career development, the most weak component is formal education. To reach a broader education, formal education is not easily done by employees hotel. The time for continuing education is limited. Especially in hospitality services still use shifting work system, then many employees have difficulties in arranging a time for work and college. So that the response to the self improvement in education more at the undergraduate level (S-1), whereas for a higher level still get a low response.

Education related to a person's career development. Career development is the process of improving the ability of individual work accomplished in order to achieve the desired career. Career development is defined as the activities carried out constantly, businesses compiled by the organization that is focused on the development and enrichment of human resources within the organization to describe the needs of employees and the organization. Besides pursued by formal education, can also be done by following number of courses and trainings. A number of courses that can be followed by a hotel employee instead of formal education include: course management, self-development courses, courses of personality, leadership courses and the course of human resource development. While training is important in supporting the development of a career in the hotel include: management training, soft skills training, leadership training, vocational training in accordance with their respective fields, training and information technology,career development undertaken by the company, career development programs to foster loyalty and the quality of an employee. Some of this training will have an impact on employees, who will be able to see the potential of latent and encourage to do something bigger. This is one factor that supports the competitiveness of human resources in the field of hospitality industry.

Academic achievement, educational background are factors to be considered in the early stages of a career. Early career in the industry generally will be affected by the education and work experience. This is because the use of education as one of the indicators to assess a person's level of skill or productivity. In this study, the academic skills of the hotel employees are mostly located in both categories.Indicators of educational background includes educational support, Grade Point Average (GPA) and colleges, the relevance of the course to support the work and the ability to master the course. This description explains that working in the hotel is prepared including the education and mastery of the subject or subjects of supporting the work in the hotel.

Most graduates are prepared to work in the hospitality industry started early in his career with a formal education background. Hull (2005) states that achievement is one thing that is appreciated by the hospitality industry for academic achievement is expected to affect a person's career in working in the industry. Employees with high academic skills can be better in performing tasks assigned to him. Educational institutions with the help of industry should provide the students with a realistic picture of the hospitality industry. Higher education institutions should work with the hospitality industry to prepare a clear and realistic picture of the industry and career path. In the industry, a hospitality manager hire someone because most aspects of the attitude and the specialized knowledge and skills. 
Technically, operational skills and diligency will always be paramount.

Dana and Peter (2012) states that the relations of education factor to the success of a potential industry is still an important area for investigation, although in this study the role of academic skills have contributed are low compared with other determinants. Each prospective employee must have higher education as they think that higher education will be entrusted as the higher achievement, have a good early career, and achieve a better career path.

In line with Ladkin (2002) stated that education is an essential starting point in the career development and is the basis of career analysis. In addition, there is a correlation between the level of educational success and career development of individuals. Individuals with higher levels of education are making progress in the organizational structure.Based on this analysis can be explained that the academic skills is indispensable for person in beginning career in the industry. After all educational backgrounds and academic achievement is one of the first factors to consider the hospitality industry to accept someone working in the company.

The hospitality industry should fully appreciate the hospitality diploma/undergraduates who began his career in the hospitality industry and do not put the same entry level with the secondary school graduates who have qualified more on work experience. Although in reality, the hospitality industry expect more employees with experience rather than thehospitality undergraduate. A bachelor's degree will give a person the advantages and disadvantages regarding work in the chosen field. It can be seen from the results that the employees of the Siantar hotel and Grand Inna Parapat Hotel with the undergraduate educational background does not have a significant difference to the skills and performance when compared with diploma $3 / 2 / 1$ and a secondary school graduates. Competencies that they have are not motivated by the educational factors but the experiences they have.

\section{Human Resources Skills}

Basically skills are categorized into four, namely:

1. Basic literacy skills

Basic skills are the skills that are uncertain and must be owned by most people, such as reading, writing and listening.

2. Technical skills

Engineering skills is an individual's expertise in the development of techniques that are owned, such as measuring accurately, operate the computer.

3. interpersonal skills

Interpersonal skills is a person's ability to interact effectively with others as well as with co-workers, such as a good listener, express opinions clearly and work within a team.

4. problem solving

Resolving the problem is the process of activities to sharpen logic, argument and problem resolution as well as the ability to determine the cause, develop alternatives and analyze and choose a good settlement.

Technical skills is the basic engineering skills for employment. In addition to technical skills is important to develop soft skills. Today, the hospitality industry in recruiting workers is more concerned with soft skills than technical skills. The comparison is $80 \%$ for soft skills and $20 \%$ for technical skills. Nevertheless, an employee must have both the soft skills and technical skills.

According to Hinckley and Hull (2008: 37) some of the skills required of human resources in your career, namely: ... (1) The employability skills, (2) career and technical skills, (3) job entry skills, and (4) advanced skills.

Vocational education is an education that prepares students to work professionally in a particular field. The graduates are expected to be ready and able to work, either independently or as an employee in the industry. Schulz (2008) states that employability skills fulfill important role in shaping an individual's personality and complement their technical skills. Employability skills including the ability to have interpersonal, work in teams, think critically, and be able to solve the problem. Employability skills or soft skills is a component of career and technical education have been identified, defined, and implanted into the curriculum.

Employability skills or also known by the term of soft skillsis a collection of non-technical skills that must be possessed by the human resources in the hospitality industry to enter the working world, to survive and to develop a career in the workplace. Employability skills aspect in this study is a basic skill, self-processing skills and skills to work in teams.Employability skillsoften referred to job skills. Employability skills are general and across all types of industry, business size, and level of jobs ranging from entry level workers to the highest position (Robinson, 2000). Employability (employability skills) depends on the knowledge, skills and attitudes, how workers use these assets and how workers demonstrated its ability for the company.

Employability skillsare the skills most desired by the industry that can be taken to all sorts of situations, the expertise to solve problems, communicate, work in teams, and think critically (Billing: 2003). Employability skills essential for career success for all levels of workers and to all levels of education (Overtoom, 2000). Basic skills possessed by the employees of the hotel include a number of the following. Employees are able to explicitly in dealing orally (verbally) with other people, communicate well, correctly and politely when speaking to everyone. Employees know how to put themselves in a different situation to other people who want to communicate, able to communicate well for the success of the work assigned by superiors, could write a report and make a good presentation. Furthermore, employees are able to listen attentively when to communicate and respond to the comments of others during communication. 
Another component in the employability skills are personal qualities. Employees have the ability to provide new solutions to a problem, working hard to do the tasks assigned by superiors, resolve problems in work with independent manner in accordance with the responsibilities. At every task, employees themselves take the initiative in improving productivity for the company's progress, have perseverance in performing their duties and can assure themselves that all work will be carried out properly and smoothly. Good qualities in employees have good confidence for each job and the decisions that they are taken taken would be good for the company, able to work with all people and be open, when reprimanded or constructive criticism.

The role of employability skills are more important than the grade point average (GPA) in the hospitality industry. Soft skills have bigger role in career advancement. Employability skills is a basic skill, selfprocessing skills and skills to work in teams. Employability skills or soft skills related to the ability of employees to think creatively in performing daily work, create ideas and communicate them to colleges, provide feedback to the company to be followed for future developments.Employees with high soft skills will tend to be fast in getting promotion, and after it reached he could pursue advanced skills are still low. Advanced skills for a the employee is the thing to do because come into one's vision and process of improvement and development capabilities of individual work accomplished in order to achieve the desired career.

In addition, career and technical skills they have when they work in the industry is also a factor that needs to be developed. This will enhance the competitiveness and support the human resources career in the hospitality industry. Job entry skills factorthat is possessed of an employee obtained when they perform in the job training in the industry. These skills are also very supportive to develop themselves and compete in the hospitality industry. In this study, the majority of employees in the hotel already have good skills. It is proven by the majority already have a certificate of competence in the field. But, for those who have not, must immediately prove that they are competent in their fields by following the process of the competency test. This is due, in this research mostly educational background of employees at the hotel where the research does not come from hospitality education. With the certificate of competence, industry will recognize the abilities and skills of an employee in the field.

\section{The Role of Triple Helix System To Improve HR Competency}

Government, academia and industry have to be able to synergize in order to meet the expectations of the employee's competency industrial world, which form the triple helix. Triple helix system can be run either by sitting together for third parties to support the improvement of human resource skills for hospitality.

\section{a. The role of Government}

Government's role is issued regulations, laws and policies that support the factors in developing the competence and competitiveness of human resources in the hospitality industry. So far, the government such as the Ministry of Tourism of the Republic of Indonesia has issued a policy to assist in the certification process of the hotel employees in Indonesia. Certification is conducted to prove that a hotel employee has the ability and competence in the field. This needs to be continuously carried out, considering not all hotel employees have been certified. While in this era of globalization throughout the hotel employees have to compete with the human resources from within and outside the country.

The government also helps maintain existing career path in the hospitality industri. The career path should be in accordance with theIndonesian National Qualifications Framework (KKNI). KKNI is levelling framework qualifying human resources in Indonesia, which is put, equalizes, and integrating education sector with training and working experience in a recognition workability scheme adapted to the structure of employment in the different sectors.

KKNI embodies the quality and identity of Indonesian relating to the national education system, national job training system, and a system of equality national learning outcomes, owned by Indonesia to produce qualified and productive human resources.

Many hotels in the hospitality industry should apply KKNI in the case of their workforce recruitment. So that the employees with Diploma 3 educational background and secondary school graduates in hospitality field will have a career path in accordance with the level of education.With the implementation of KKNI, human resources in the hospitality sector will be able to compete confidently, according to the science and educational background they have.

\section{b. The role of Academics}

The role of academics tend to solve the problems in an educational context. Academics must adapt the curriculum that required by the industry and regulations issued by the government. Career and Technical Education developed since 2005. This law will continue in repairing career paths for students from high school to academic institutions and become a labor/workforce.

Vocational education continues to strive so that the graduates can have good qualities. Career and Technical skills can be gained to the maximum with some support. Vocational education will be efficient when provided a learning environment that suits the environment in which they will work. Effective vocational training can only be granted if the assigned task in practice have the same operational with equipment and machines similar to those used in the workplace. Vocational education will be effective if since exercise is already accustomed to the behavior which should be addressed in 
future work experience. Vocational education instructors must be experienced and apply the skills in teaching. Education must be familiar with working conditions and must meet the market. The most appropriate data source for determining the educational material is an experience that is closely connected with the work.

The knowledge and skills included in the career and technical skills are part of the curriculum that will be required for the graduates at the same time to start a career as well as the next steps in the path of his career (Hull \& Hinckley, 2008). According Kepmendiknas No. $045 / \mathrm{U} / 2002$, which referred to the competence is a set of intelligent action, the full responsibility of a person as a condition to be considered capable by the public in carrying out tasks in certain occupations. In accordance with the Decree of the Minister of Manpower and Transmigration No. 2292003 is the job competencies is the ability of each individual that covers aspects of knowledge, skills, and attitudes that work in accordance with established standards. Competence includes aspects of knowledge, skills and attitude about work in a particular field.

Educational background for an employees is important as an indicator of the individual ability work accomplished in order to achieve the desired career. This is helpful to start the career in the hospitality industry. In fact, in the hospitality industry, educational background is not an important thing to look at when hiring a graduate. Diploma 3 and secondary school graduates can have the same entry level in starting their careers. The role of academics becomes important, to be able to put their positions at the suitable level matching to the educational background and required by the industry.

\section{c. The role of The Industry}

More industrial role in the development of job entry skills obtained by a person at the job training and career advancement that can be achieved in the hospitality industries. Career can be reached through the promotion, which require upgrading of skills and education.Career path is the path of the first level of a career to get to the last level (the highest), through the stages of work, personal development, experiential learning and promotion. Career path is the job sequence pattern that must be traversed by employees to achieve career goals. Career path is formal, ideal, normative and determined by the organization (not the employee) with the assumption that every employee has the same opportunity to achieve specific career goals. On this career path, career mobility is the most maximal indicator performed by the employee, and then followed by work experience. While the promotion descriptively, the majority of employees are still not optimal in gaining promotion.

Hotel has implemented the right career path for employees, and employees are able to recognize the career path at the company work. Career mobility from company to company is an important factor in developing the career paths. As more, working experience in some hotel, will be better in supporting career paths. Work experience steeped in more than one department, will affect the progress of the career path. Each employee will strive to develop themselves with career planning that has been made. Promotion is one factors of career development. Most employees have a starting position of rank $n$ file. Positions at the beginning of his career while working in the hotel is an important factor for career success in the future. When on the job training experience (industry working practices) during the school/college will affect the recruitment to be an employee. Graduates who have practical experience in the international chain hotel management is better than graduates who had practical experience in the hotel were not international chain hotel management in starting their career. Work experience as doing freelance workers or part-time job in the industry before graduating is a provision at the time of starting a career in the industry.

In terms of on the job training, the hospitality industry should cooperate with educational institutions and vocational training of hospitality and tourism to produce the professional graduates that expected in the industry.

Promotion opportunities provided by the company implies that companies doing business employee development through a clear career path so that employees are motivated to work and achieve. At a later stage, the company's operational continuity will be assured. A company usually has a mechanism or system in doing promotion. Based on the above statement, it can be stated that the role of industry is very important in improving the competitiveness of human resources in the hospitality industry.

\section{CONCLUSION}

The results of the analysis and discussion in the previous section, we obtain some conclusions, as follows:

1. Human resourcesof Grand Inna Parapat Hotel and Siantar hotel Parapat most have secondary school education level background. However, the research results prove that the competence of employees with secondary school education background does not have a significant difference compared to employees with educational background of diploma 3/degree. This is not an obstacle, because the hotel employees are equipped with a variety of training appropriate to the field and profession of each.

2. Employees' competency of the hospitality prepared since being at secondary school. They have mostly been certified. For employees who are not yet certified, should follow competency test or assessment so that the human resources competencies are able to have a competitive edge in the hospitality industry.

3. 'Triple helix' role system (industry, government and academics) have not been well integrated. The industry should continue to link and match with the government and academicsas a mutualism system. 


\section{REFERENCES}

Asyhari dan Wasitowati. 2015. Hubungan Triple Helix, Inovasi, Keunggulan Bersaing dan Kinerja. Proceeding of $2^{\text {nd }}$ conference in business, accounting and management. Semarang. Vol 2: 320-334

Billing, D. 2003. Generic Cognitive Abilities in Higher Education: An International Analysis of Skills Sought by Stakeholders. Compare. 33(3) : 335-350.

Dana V.,T., \& Peter R. 2012. Hospitality Industry Expectations of EntryLevel College Graduates: A Preference for Attitude over Aptitude. European Journal of Business and Social Sciences. (Online) $1 \quad$ (6) $\quad: 140 \quad-\quad 149$. (http://www.ejbss.com/recent.aspxISSN: 2235 -767X), diakses 23 Mei 2013.

Dalimunthe, Femmy. 2017. Jalur Karier Lulusan SMK dan Diploma III Bidang Perhotelan pada Hotel Berbintang di Kota Medan. Disertasi. Malang

Dessler, G. 2009. Manajemen Sumber Daya Manusia. Jakarta : Edisi Kesepuluh Jilid Dua. Jakarta : Indeks.

Etzkowitz, H \& Dizisah, J., 2008, Triple Helix Circulation : the heart of innovation and development, International Journal of Tecnology Management and Sustainable Development, Volume 7: 101- 115

Hinckley, R., \& Hull, D. 2008. Adult Career Pathways: Providing a Second Chance in Public Education. Texas: CORD.

Hull, D. 2005. Career Pathways: Education with a Purpose. Texas:CORD

KEP.239/MEN/X/2004 tentang Penetapan SKKNI Sektor Pariwisata Subsektor Hotel dan Restoran.

Kong, H., Cheung, C.,\& Zhang, H., 2010. Career management systems: what are China's state- owned hotels practicing. International Journal of Contemporary Hospitality Management . 22 (4) : 467-482.

Ladkin, A. 2000. Vocational Education and Food and Beverage Experience: Issues for Career Development. International Journal of Contemporary Hospitality Management. 12 : 226-223.

Ladkin, A. 2002. Career Analysis : A Case Study of General Hotel Managers in Australia. Tourism Management. 23 :379:388.

Ladkin, A., \& Juwaheer, T.,D. 2000. The Career Paths of Hotel Managers in Mauritius. International Journal of Contemporary Hospitality Management. 12: 119-125.

Ladkin, A., \& Riley, M. 1996. Mobility and Structure in The Career Paths of UK Hotel Managers : A Labour Market Hybrid of The Bureaucratic Model. Tourism Management. 17: 443452

O’Leary, S. \& Deegan, J. 2005.Career progression of Irish Tourism and Hospitality Management Graduates.International Journal of Contemporary Hospitality Management. 17 (5) : 421-32.

Overtoom, C. 2000. Employability Skills: An Update. (Online), (http://www.calpro-online.org), diakses 9 Januari 2014.

Rivai, Veithzal .2004. Manajemen Sumber Daya Manusia untuk Perusahaan. Jakarta : PT.Murai Kencana

Rivai, Veithzal. 2008. Manajemen Sumber Daya Manusia Untuk Perusahaan dari teori ke praktik. Jakarta: PT. Rajagrafindo Persada.

Robbin, Stephen P.2010.Perilaku Organisasi. Jakarta: PTINDEKS Kelompok Gramedia:357.

Schulz, B. 2008. The Importance of Soft Skills:Education Beyond Academic Knowledge. Journal of Language and Communication, (Online): 145-154, (hhtp://ir.polytechnic.edu.na) diakses 11 Desember 2014

Spencer and Spencer. 1993. Competence at Work: Model for Superior Performance, John Wiley \&Sons, Inc, New York: 9 - 11

William B. Werther Jr dan Keith Davis. 1996. Human Resources and Personnel Management, Eight Edition. New York : Irwin Mc. Grow Hill.

Yuniarsih, Tjutju dan Suwatno. 2008. Manajemen Sumberdaya Manusia, Alfabeta:22. 